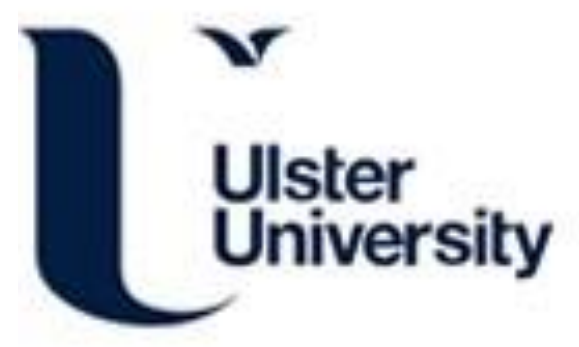

\title{
The Use of Legal Software by Non-lawyers and the Perils of Unauthorised Practice of Law Charges in the United States: A Review of Jayson Reynoso Decision
}

Oriola, T. (2010). The Use of Legal Software by Non-lawyers and the Perils of Unauthorised Practice of Law Charges in the United States: A Review of Jayson Reynoso Decision. Artificial Intelligence and Law, 18(4), 250275. https://doi.org/10.1007/s10506-010-9103-y

Link to publication record in Ulster University Research Portal

Published in:

Artificial Intelligence and Law

Publication Status:

Published (in print/issue): 01/12/2010

DOI:

10.1007/s10506-010-9103-y

Document Version

Publisher's PDF, also known as Version of record

\section{General rights}

Copyright for the publications made accessible via Ulster University's Research Portal is retained by the author(s) and / or other copyright owners and it is a condition of accessing these publications that users recognise and abide by the legal requirements associated with these rights.

\section{Take down policy}

The Research Portal is Ulster University's institutional repository that provides access to Ulster's research outputs. Every effort has been made to ensure that content in the Research Portal does not infringe any person's rights, or applicable UK laws. If you discover content in the Research Portal that you believe breaches copyright or violates any law, please contact pure-support@ulster.ac.uk. 


\title{
The use of legal software by non-lawyers and the perils of unauthorised practice of law charges in the United States: a review of Jayson Reynoso decision
}

\author{
Taiwo A. Oriola
}

(C) Springer Science+Business Media B.V. 2010

\begin{abstract}
This paper critically reviews the judgment of the United States Court of Appeals for the Ninth Circuit In re: Jayson Reynoso: Frankfort Digital Services et al., v. Sara L. Kistler, United States Trustee et al. (2007) 447 F.3d 1117. The appellants, who were non-lawyers, were indicted with unauthorised practice of law for offering bankruptcy petition services via online legal software or expert systems in law configured for filing bankruptcy petition forms. The United States Court of Appeals for the Ninth Circuit found inter alia that appellants were bankruptcy petition preparers, and not being lawyers, had exceeded their clerical remit by offering legal advice and legal services in contravention of California law regulating legal practice and 11 U.S.C. Sect. 110 of the Bankruptcy Code (2002). While examining the legal ramifications of the use of legal software by non-lawyers in the preparation of legal documents, the paper critically reviews the factual circumstances of the Reynoso decision in the context of juridical and statutory constructs of unauthorised practice of law in the United States. The paper poses the question whether Reynoso should be viewed as a one-off decision bound by its peculiar facts, or good law for the broad proposition that non-lawyers cannot use legal software in legal documents preparation. The paper also notes the possible legal barriers to an unconditional ban on the design, sale, distribution, and uses of legal software by non-lawyers. These range from the First Amendment right to free speech, constitutional right to pro se legal representation, interstate commerce doctrine, to antitrust provisions of the Sherman Act. A regime of best practices for the use of legal software or expert systems in law by non-lawyers is proffered.
\end{abstract}

Keywords Legal software - Expert systems in law - Non-lawyer use of legal software - Unauthorised practice of law charges

\footnotetext{
T. A. Oriola $(\bowtie)$

The School of Law, University of Ulster, Northland Road, Londonderry BT48 7JL, UK

e-mail: T.oriola@ulster.ac.uk
} 


\section{Introduction}

In Great Britain, the Law Society's exclusive monopoly on conveyancing services was loosened in 1987 (Leef 1997). ${ }^{1}$ This contrasts sharply with the United States, where the legal profession jealously guards its turf by fencing-off non-lawyers from conveyancing, legal documents preparation, or any activities that are perceived as the traditional preserves of lawyers or statutorily defined as the practice of law (Lanctot 2002). Ostensibly, the main policy rationale for this prohibition is legal services quality assurance and the protection of the public from unqualified legal practitioners, who while appropriating the full benefits of legal practice, often eschew the corresponding responsibilities that traditionally underpin the attorney and client relationship (Fischer 2000-2001). ${ }^{2}$ For example, the British firm, Desktop Lawyer, which sells customised online and offline legal documents for personal and business uses via its "Rapidocs" software, operates a disclaimer policy that expressly absolves the firm from any liability associated with the use of its "intelligent" legal documents. ${ }^{3}$ Ditto LegalZoom, a similar online firm based in the United States, which sells legal information and documents. It describes itself as a provider of legal document services, and would not be drawn into "an attorney-client relationship" with its customers. ${ }^{4}$ The aforesaid firms' reluctance to assume responsibility for any liability arising from their quasi-legal services or enter into any confidential relationships akin to that of attorney and client relationship, is arguably informed by the ground rules prohibiting lay persons from representing themselves as lawyers (Messina 2000).

Even then, the brazenness of non-lawyers cashing in on legal or quasi-legal services, while disclaiming responsibility for liabilities arising from their activities, has fueled resentments from opponents such as Gibeaut (1998) ${ }^{5}$. For example, while decrying the incursions of accountants on lawyers' turf, Gibeaut argued that accountants could not "offer broad-ranging confidentiality or loyalty and the protections that those duties try to guarantee", and warned that if legislators would not stop accountants' dabbling in legal practice, the legal profession would become indistinguishable from accounting overtime. ${ }^{6}$ Gibeaut's views are but symptomatic of the fierce vocational turf fencing (often rightly fortified by prescriptive educational training and compulsory professional membership) that generally characterise the professions such as medicine,

\footnotetext{
${ }^{1}$ In Britain, the deregulation of conveyancing services in 1987 by the Thatcher government opened legal services market to licensed conveyancers who were not members of the legal profession, with dramatic decrease in conveyancing fees. See Leef (1997) (Winter 1997), at http://www.cato.org/pubs/regulation/ regv20n1/reg20n1c.html (last accessed on 2 August 2010). However, while laypersons are not expressly prohibited from giving legal advice, they cannot misrepresent themselves as legal specialists. See Messina (2000), at 327.

2 Fischer (2000-2001); Ohio State Bar Association v. Newburn (2008) 119 Ohio St.3d 96, where Ohio Supreme Court held inter alia that "Our jurisdiction thus extends to regulating unauthorized practice of law, which we do to protect the public from agents who have not been qualified to practice law and who are not amenable to the general discipline of the court." Ibid., at 97.

3 Online and offline documents on offer vary from wills, divorce, employment contract to agency contract. See www.desktoplawyer.co.uk (accessed on 2 August 2010).

4 See http://www.legalzoom.com/disclaimer-popup.html (accessed on 2 August 2010).

5 Gibeaut (1998), at 42 and 47.

6 Ibid.
} 
engineering, accounting, etc., and is by no means peculiar to the legal profession. Thus Gibeaut's views could be reasonably and logically extrapolated to the following rhetorical question: if lawyers could not dabble in surveying or accountancy, why should surveyors and accountants dabble in legal practice?

However, critics have fingered a more self-serving motive for views such as Gibeaut's that back enforced exclusion of non-lawyers from legal documents preparation, or offering of legal or quasi legal services in the United States: the fostering of an exclusive cartel with an unbridled stranglehold on legal practice (Fischer 2000-2001). ${ }^{7}$ This perceived monopoly on conveyancing or legal documents preparation by members of the Bar in the United States, has been directly implicated in the characteristically expensive legal services, and has given rise to the perception of constraints on consumers' choice (Leef 1997). ${ }^{8}$

Perhaps then, US lawyers' monopoly on conveyancing and legal documents preparation is an anachronism or a two-edged sword that could at once protect and harm the consumer? There is certainly a balance to be struck, and the British government certainly thought it expedient to loosen the Law Society's monopoly on conveyancing practice in 1987 , by opening up the market to licensed conveyancers who were not necessarily members of the legal profession. ${ }^{9}$ The policy deregulating conveyancing services in Britain however precludes non-lawyers from representing themselves as lawyers or legal experts (Messina 2000). ${ }^{10}$

Even in the United States where the market in legal services is exclusive to members of the Bar, lawyers' monopoly on legal practice as such, is at best tenuous, and has hardly ever been absolute or exclusive. Historically, professionals such as accountants, real estate managers and other professions with ancillary interests in the preparation of tax documents, bankruptcy documents, leases, conveyances, and other legal and quasi-legal documents have fought back at the perceived legal practitioners' monopoly with a relative degree of success (Rentz 2005; Justice 1991). ${ }^{11}$

Significantly, others on the outer periphery such as paralegals and bankruptcy petition preparers are restricted to the clerical work of typing legal documents rather than preparing them or advising on their contents. ${ }^{12}$ However, information

\footnotetext{
7 Fischer (2000-2001), supra, note 3, at 138-139.

8 Leef (1997), supra, note 1.

9 Ibid.

${ }^{10}$ Messina (2000), supra, note 1, 367, at 372. As noted above, this probably explains why the British firm, Desktop Lawyer, would not assume responsibilities inherent in lawyer-client relationships. See notes 4 and 5, supra.

11 Justice (1991, 179), Rentz (2005, Fall), Schwab (2000), Palomar (1991). However, for most, the unauthorised practice of law huddle remains an implacable barrier. This is exemplified by the 2008 Ohio Supreme Court decision, which found a professional surveyor whose work involved incidental preparation of conveyances, liable for unauthorised practice of law. The Court had held that the “... practice of law embraces the preparation of legal documents on another's behalf, including deeds which convey real property." See Ohio State Bar Association v. Newburn, supra, note 3, at 97.

12 For example, in New York County Lawyers' Association v. Dacey, 283 N.Y.S. 2d 984, at 990, (App. Div.), Revised 234 N.E.2d 459 (N.Y. 1967). It was held inter alia that " $\mathrm{t}$ ] he copying or completion of a form may consist merely of clerical work but the selecting of the proper form and telling a clerk what to copy and how to fill in the blanks is lawyers' work." Also in Ohio State Bar Association v. Newburn, supra, note 3, at 97, the Ohio Supreme Court noted that the practice of law embraced the preparation of legal document.
} 
technological tools such as legal software and the internet have blurred the fuzzy boundaries between clerical chores of typing of legal documents and legal documents preparation or offering of legal advice, thus rendering bankruptcy petition preparers and paralegals vulnerable to the perils of unauthorised practice of law charges. However, before reviewing the US Court of Appeals decision in the Reynoso case, it is apt to briefly discuss the phenomenon of legal software or expert systems in law and its revolutionary impacts on legal information dissemination and access.

\section{Legal software or expert systems in law defined}

In general terms, expert systems are an amalgam of artificial intelligence and specific body of knowledge configured to execute tasks, solve problems, and proffer advice that is otherwise the prerogative of human intelligence (Susskind 2000). ${ }^{13}$ In the realm of legal information science, expert systems in law or legal software are specifically programmed for legal information retrieval, legal reasoning and problems solving, drawing on critical legal database resource or knowledge. ${ }^{14}$ Although the use of expert systems in law for judicial decision support, legal information management and retrieval by judges, legal academics and lawyers is sacrosanct, ${ }^{15}$ its use for legal reasoning and advice has not yet been satisfactorily programmed, and have had relatively limited successes (Oskamp and Lauritsen 2002). ${ }^{16}$ Nevertheless, expert systems in law or legal software programs offering commercial online and offline computer-mediated legal services are now ubiquitous (Lanctot 2002), ${ }^{17}$ with concomitant legal externalities, ranging from malpractice risks for lawyers, ${ }^{18}$ breaching of multi-jurisdictional practice restriction rules (Glass and Jackson 2000-2001), ${ }^{19}$

13 The ubiquitous cash dispenser machines are an example of expert systems. For discussion, see Susskind (2000), at 162-176.

14 See Susskind (1987) at 3.

15 For example, legal information retrieval systems such as WESTLAW and LEXIS are crucial expert systems for legal academia and the legal profession. For discussion, see Susskind (2000), supra, note 14 at 221-222.

16 Oskamp and Lauritsen (2002), Susskind (1987), supra, note 15 at 3.

17 For discussion, see Lanctot 2002, supra, note 2, at 811-854.

18 Susskind suggested that legal advisers could most certainly be held liable for resultant losses from negligent advice proffered using expert systems in law. See Susskind (1996). See also Morrison (1989). The author opined that concerns for potential malpractice liability risks were a major obstacle to widespread adoption of rule-based expert systems by lawyers. Ibid; at 34 .

19 The American Bar Association, Report of the Commission on Multi-jurisdictional Practice defines the term as "...the legal work of a lawyer in a jurisdiction in which the lawyer is not admitted to practice law." See American Bar Association Centre for Professional Responsibility, Client Representation in the 21st Century: Report of the Commission of Multi-jurisdictional Practice (August, 2002), at http://www.judiciary.state.nj.us/notices/reports/abareport.pdf (assessed on 2 August 2010). The inherent multi-jurisdictional nature of online practice of law by lawyers is a concomitant externality to the increasing use of modern telecommunication technologies in legal practice. See for example the California Supreme Court dicta in Birbrower, Montalbano, Condon \& Frank, P.C., v. Superior Court of Santa Clara County. 949 P.2d. at 4. The Birbrower court opined that a lawyer not physically present in California could still be deemed to practice law in contravention of California law forbidding out-of-state 
to potential charges of unauthorised practice of law for non-lawyers in the United States. $^{20}$

Significantly, the parameters of the conditions for use, and the legal ramifications of the use of expert systems in law or legal software by non-lawyers remain as yet tangled due to the inherent ambiguity on what constitutes the practice of law in the United States. ${ }^{21}$ The pertinent questions therefore are: How could non-lawyers who use legal software escape possible unauthorised practice of law charges? Should the Reynoso decision, where the Court of Appeals held that the use of a bankruptcy petition software constituted unauthorised practice of law, be viewed as a one-off decision bound by its peculiar facts and merits, or good law for the general proposition that non-lawyers, using expert systems in law are generally engaged in unauthorised practice of law? Employing the factual circumstances of the Reynoso decision as a backgrounder, the paper will answer these questions in light of juridical and statutory constructs of unauthorised practice of law in the United States.

\section{The decision}

A. In re: Jayson Reynoso: Frankfort Digital Services et al., v. Sara L. Kistler, United States Trustee, et al. ${ }^{22}$

Appellants Henry Ihejirika and Frankfort Digital Services, Ltd.; operated a webbased bankruptcy software, which generated complete bankruptcy petitions schedules, and statements of financial affairs from information entered by patron bankruptcy petitioners in dialogue boxes on the web-based expert systems at "700law.com" and "Ziinet.com". ${ }^{23}$ Ihejirika was an entrepreneur who owned and conducted businesses as Frankfort Digital Services via the said websites. ${ }^{24}$ The websites sold licenses to debtors to access web-based bankruptcy documents preparation software. Neither of the appellants (Ihejirika and Frankfort Digital Services) was an attorney. ${ }^{25}$

On 30 January 2002, Jayson Reynoso, a debtor, paid $\$ 219$ for the use of appellants' web-based "Ziinet Bankruptcy Engine" to prepare his bankruptcy

\footnotetext{
Footnote 19 continued

practice of law, if he advised a California resident client via telephone, fax, computer, or other modern technological means. Ibid. For discussion, see Glass and Jackson 2000-2001.

${ }^{20}$ This is exemplified by the case of In re: Jayson Reynoso, Debtor, Frankfort Digital Services, LTD.; Henry Ihejirika, Appellants, v. Sara L. Kistler, United States Trustee, Appellee, and Executive Office of United States Trustee, Trustee. (2007) 477 F.3d 1117.

${ }^{21}$ Lanctot (2002), supra, note 2 at 811-822, Glass and Jackson 2000-2001, supra, note 21 at 1195.

22 Ibid, at $1117-1126$.

${ }^{23}$ The facts of the Reynoso decision as restated here are drawn from the decision of the United States Bankruptcy Appellate Panel for the Ninth Circuit in re: Jayson Reynoso, Debtor. Frankfort Digital Services, LTD.; Henry Ihejirika, Appellants, v. William T. Neary, United States Trustee, Appellee. (2004) 315 B.R. 544, at 547-554.

${ }^{24}$ Ibid.

${ }^{25}$ Ibid.
} 
petition and schedules. ${ }^{26}$ "Ziinet", the website hosting the bankruptcy engine, advised prospective customers in the United States on how to "Keep BK Off Your Credit," "Keep Everything Even 4 Or 5 Cars," and "File bankruptcy and keep it out of your credit report!" 27 The website further guaranteed that "Ziinet" would automatically select bankruptcy exemptions, ${ }^{28}$ and then vouched for the competency of the "Ziinet" bankruptcy engine as follows:

Ziinet is an expert system and knows the law. Unlike most programs which are little more than customized word processors the Ziinet engine is an expert system. It knows bankruptcy laws right down to those applicable to the state in which you live. Now you no longer need to spend weeks studying bankruptcy laws. $^{29}$

On 30 January 2002, Reynoso was advised by the appellants via email that he could access "The Vault" purportedly housing "bankruptcy secrets" ranging from how to keep a bankruptcy off a credit report, to how to protect "more than your fair share of assets." ${ }^{30}$ During trial, Reynoso testified that he declined to use this option because he feared being confused and thought "it wasn't right to do things like that." ${ }^{31}$ Reynoso also testified that he filed his bankruptcy petition, scheduling, and statements on 28 February 2002 by entering his identification, assets, debts, income, etc., into dialog boxes of the web-based Ziinet bankruptcy software. ${ }^{32}$ The bankruptcy software then automatically generated completed bankruptcy forms with instructions on how to print them. ${ }^{33}$

However, the completed forms generated by Ziinet bankruptcy engine were beset with errors and misrepresentations. First, Reynoso crucially failed to list his household goods and personal clothing items on the filed schedules. He testified that he was led on by the software instructions to believe that he was not required to list those assets. ${ }^{34}$ Second, neither the signature nor the social security number of the non-attorney bankruptcy petition preparer were entered in the allocated space on the bankruptcy form, as required by the Bankruptcy law under oath. Instead, the bankruptcy software generated an automated answer to the effect that Reynoso prepared the bankruptcy petition on his own and without the assistance of an attorney, paralegal or a bankruptcy petition preparer. $^{35}$ This was a significant misrepresentation that bordered on perjury and the court of first instance and

\footnotetext{
26 Ibid.

27 Ibid.

28 Ibid.

29 Ibid.

30 Ibid.

31 Ibid.

32 Ibid.

33 Ibid.

34 Ibid.

35 Ibid.
} 
appellate courts used it as evidence of fraudulent, unfair and deceptive conduct by the appellants. ${ }^{36}$

The Chapter 7 trustees (the appellee) brought an action against the appellants in the United States Bankruptcy Court for the Northern District of California for alleged violations of 11 U.S.C. Sect. 110 of Federal Bankruptcy Code (2002); unauthorised practice of law under California law; and fraudulent, unfair and deceptive conduct. ${ }^{37}$ The lawsuit sought fines and disgorgement of fees paid by Reynoso to the appellants. It also sought a perpetual injunction barring appellants from further acting as bankruptcy petition preparers or engaging in unauthorised practice of law contrary to California law. ${ }^{38}$

\subsection{The ruling of the United States Bankruptcy Court for the Northern District of California}

The Bankruptcy Court for the Northern District of California ruled inter alia that appellants were bankruptcy petition preparers, and being non-lawyers, had engaged in unauthorised practice of law. ${ }^{39}$ Appellants' argument to the contrary that they merely owned a website, which allowed access to bankruptcy software by debtors across the United States, was rejected by the Bankruptcy Court as follows:

Websites don't just grow out of thin air and aren't maintained out of thin air. They're put together by people; they're put on the Internet; and it's not the website that provides the assistance. It's the people who develop website that provide the assistance. ${ }^{40}$

The Bankruptcy Court further held that appellants had intentionally concealed their actions as bankruptcy petition preparers, and engaged in fraudulent, unfair, and deceptive conduct, and had intentionally violated 11 U.S.C. Sect. 110 of Bankruptcy Code (2002). ${ }^{41}$ The Bankruptcy Court then assessed fines; ordered a refund of \$219 fees paid by Reynoso to the appellants, and permanently enjoined the appellants from acting as bankruptcy petition preparers, and engaging in unauthorised practice of law. ${ }^{42}$ The appellants were dissatisfied, and appealed the ruling of the Bankruptcy

\footnotetext{
36 Ibid.

37 Ibid.

38 Ibid.

39 The Bankruptcy Court for the Northern District of California's ruling restated here, is as gleaned from the ruling of the United States Bankruptcy Appellate Panel for the Ninth Circuit in re: Reynoso, Jayson, (Debtor) Frankfort Digital Services, Ltd.; Henry Ihejirika (Appellants) v. William T. Neary, United States Trustee, (Appellee) supra, note 24. There is no recorded opinion of the Bankruptcy Court for the Northern District of California in the Reynoso case. However, a related proceeding (with identical facts involving a different debtor but same appellants Frankfort Digital Services et al.,) was heard by the United States Bankruptcy Court for the Central District of California, Los Angeles Division, and reported in re: Christiana Pillot, 2002 Bankr. LEXIS 1334.

${ }^{40}$ Excerpted from the Bankruptcy Court for Northern District of California's Transcript, 44:3-8, and cited in re: Reynoso, supra, note 24 , at 552.

41 Ibid.

42 Ibid.
} 
Court for the Northern District of California to the United States Bankruptcy Appellate Panel for the Ninth Circuit.

\subsection{The ruling of the United States Bankruptcy Appellate Panel for the Ninth Circuit}

In the Appeal before the United States Bankruptcy Appellate Panel for the Ninth Circuit, the main issues for determination were: First, whether the Bankruptcy Court erred in holding that appellants were bankruptcy petition preparers. Second, whether the Bankruptcy Court erred in holding that appellants engaged in unauthorised practice of law. Third, whether the Bankruptcy Court erred in holding that appellants were engaged in fraudulent, unfair, or deceptive conduct and whether the appellant should refund all fees paid for the use of the bankruptcy software. ${ }^{43}$ The Bankruptcy Appellate Panel affirmed the judgment of the Bankruptcy Court for the Northern District of California, and held inter alia that appellants were bankruptcy petition preparers under 11 U.S.C. Sect. 110(a)(1). ${ }^{44}$ In the Bankruptcy Appellate Panel's words:

The plain language of Sect. 110(a) supports the bankruptcy court's finding that appellants are BPP (bankruptcy petition preparers) - they (through their websites) transformed raw information into completed bankruptcy forms for filing in the court, and charged fees for this service. There is no significant difference between what appellants did and the more familiar law office (or BPP) practice of obtaining information from clients on input forms and recasting that data into appropriate forms or pleadings for filing. That appellants did so electronically, at a distance and by programming software, does not change the nature of their operation; their arguments to the contrary are unconvincing. ${ }^{45}$

The United States Appellate Panel held further that appellants were engaged in unauthorised practice of law under California law, which defines legal practice as “...legal advice and counsel preparation of legal instruments and contracts by which legal rights are secured although such matter may or may not be pending in a court." 46 The Appellate Panel expatiated on the elements of unauthorised practice of law charges as follows:

Solicitation of information which is then translated into completed bankruptcy forms is the unauthorized practice of law, whether by website or otherwise, as is advising a debtor of the availability of particular exemptions...Appellants do not dispute that their software solicits information from users, that it directs them to the applicable sections of the California Code of Civil Procedure for exemptions, and that it transforms the raw data into completed forms. The

\footnotetext{
43 Ibid.

44 Ibid.

45 Ibid.

46 Ibid.
} 
bankruptcy court did not err in concluding that appellants engaged in unauthorized practice of law. ${ }^{47}$

Moreover, the appellants admitted that they neither entered their signatures nor social security numbers as required under 11 U.S.C. Sect. 110(b) (c) for nonattorney bankruptcy petition preparers, nor filed a declaration as to fees as required under 11 U.S.C. Sect. 110(h). The Appellate Panel used this admission to find that appellants had made false statements to the court and intentionally concealed their involvement as bankruptcy petition preparers. The Panel held further that this conduct was fraudulent, unfair, and deceptive, and went on to enjoin the appellants from acting as bankruptcy petition preparers in violations of 11 U.S.C. Sect. $110{ }^{48}$

\subsection{The ruling of the United States Court of Appeals for the Ninth Circuit}

Dissatisfied with the judgment of the Appellate Panel, the appellants further appealed to the United States Court of Appeals for the Ninth Circuit. ${ }^{49}$ On the question of whether appellants were bankruptcy petition preparers, the Court of Appeals extensively reviewed the provisions of 11 U.S.C. Sect. 110(a) (1) of the U.S. Bankruptcy Code which defines a bankruptcy petition preparer as “.... person, other than an attorney or an employee of an attorney, who prepares for compensation a document for filing." 50 The Court of Appeals rejected appellants' argument that "...the creation and ownership of a software program used by a licensee to prepare his or her bankruptcy forms is not preparation of a document for filing under the statute," and held that the software at issue qualified as a bankruptcy petition preparer. ${ }^{51}$ The Court of Appeals then affirmed the rulings of the Bankruptcy Court and the Bankruptcy Appellate Panel that the appellants were bankruptcy petition preparers under the statute, and held inter alia as follows:

In sum, for a fee, Frankfort provided customers with completed bankruptcy petitions. Customers merely provided the data requested by the software and printed the finished forms. This is materially indistinguishable from other cases in which individuals or corporations have been deemed bankrupt petition preparers. ${ }^{52}$

Having found that the appellants were bankruptcy petition preparers, the Court of Appeals held further that appellants exceeded their clerical remit under 11 U.S.C. Sect. $110(\mathrm{k})$ by practising law, since the services of bankruptcy petition preparers

\footnotetext{
47 Ibid.

48 Ibid; at 553.

49 In re: Jayson Reynoso, (Debtor), Frankfort Digital Services, Ltd.; Henry Ihejirika, (Appellants), v. Sara L. Kistler, United States Trustee, (Appellee), and Executive Office of United States Trustee, (Trustee). Supra, note 21 at 1119-1126.

50 Ibid; at 1123.

51 Ibid.

52 Ibid.
} 
were strictly limited to clerical typing of information into bankruptcy forms. ${ }^{53}$ The Court of Appeals further noted that while bankruptcy petition preparers could provide services solely by typing, it was not permissible for them to provide legal advice and legal services as the appellants had done. ${ }^{54}$ The Court noted further that whether or not a given activity constituted an unauthorised legal practice depended on the underlying peculiar context and circumstances. ${ }^{55}$ The court found that the bankruptcy software in question provided more than clerical services by determining where to place information provided by the debtor and supplying legal citations. ${ }^{56}$ The Court noted that this was against California law regulating legal practice, and then drew on Baron v. City of Los Angeles, ${ }^{57}$ which established that California law has long accepted that "the practice of law... includes legal advice and counsel and the preparation of legal documents and contracts." 58 The Court then ruled that under the factual circumstances of the case, appellants' offer of legal advice and services contravened 11 U.S.C. Sect. $110(\mathrm{k})$ and California law regulating legal practice. ${ }^{59}$ Significantly, the Court of Appeals' findings that appellants' conduct constituted unauthorised practice of law were premised on a combination of factual circumstances (other than appellants' mere use of bankruptcy preparation software) that underpinned the modus operandi of appellants' business. In the Court's words:

Several features of Frankfort's business, taken together, lead us to conclude that it engaged in the unauthorized practice of law. To begin, Frankfort held itself out as offering legal expertise. Its websites offered customers extensive advice on how to take advantage of so-called loopholes in the bankruptcy code, promised services comparable to those of a "top-notch" bankruptcy lawyer, and described its software as an "expert system" that would do more than function as a "customized word processor. 60

The Court of Appeals then affirmed the lower courts' rulings to the effect that appellants had engaged in fraudulent, unfair, or deceptive conduct, that they should refund all fees paid for the use of their bankruptcy software, and that they should be permanently enjoined from unauthorised legal practice or practising as bankruptcy petition preparers. $^{61}$

\footnotetext{
53 Ibid., at 1125. At the commencement of the trial section $110(\mathrm{k})$ of Chapter 11 of the U.S. Bankruptcy Code (2002) did not specifically prohibit unauthorised legal practice. It provided that "Nothing in this section shall be construed to permit activities that are otherwise prohibited by law, including rules and laws that prohibit the unauthorized practice of law". However, an amendment to the Bankruptcy Code via the Bankruptcy Abuse Prevention and Consumer Protection Act 2005 (BAP-CPA), Pub. L. No. 109-8, 119 Stat. 23, specifically barred bankruptcy petition preparers from providing legal advice. See Sect. 110(e) (2) of the Bankruptcy Abuse Prevention and Consumer Protection Act, ibid.

54 In re: Jayson Reynoso, supra, note 21 at 1125.

55 Ibid.

56 Emphasis is mine. Ibid.

57469 P. 2d 353 (1970).

58 In re Jayson Reynoso, supra, note 21 at 1125.

59 Ibid.

60 Ibid.

61 Ibid.
} 


\section{Discussion}

The pertinent question is whether Reynoso is good law for a broad proposition that non-lawyers cannot use expert systems in law or legal software in the United States? Arguably, the answer would invariably depend on the factual circumstances of each case because, and significantly, neither the facts of the case nor the decision of the United States Court of Appeals for the Ninth Circuit expressly validate such a broad proposition. ${ }^{62}$ The Court actually declined to express any views on whether the use of legal software alone, or other types of computer programs would as such constitute the practice of law. ${ }^{63}$ However, the Court did observe that the bankruptcy software in Reynoso provided more than clerical services by automatically determining where to place information provided by the debtor and supplying legal citations. This according to the Court amounted to legal documents preparation and offering of legal advice. ${ }^{64}$

The software did, indeed, go far beyond providing clerical services. It determined where (particularly, in which schedule) to place information provided by the debtor, selected exemptions for the debtor and supplied relevant legal citations. Providing such personalized guidance has been held to constitute the practice of law. ${ }^{65}$

It would thus appear from the above that while the non-lawyer use of legal software is not prohibited as such, non-lawyers could still be liable for unauthorised practice of law if the legal software in question exceeded its clerical remit, ${ }^{66}$ by preparation of legal documents or proffering of legal advice. Preparation of legal documents by non-attorneys is generally equated with legal advice, and would amount to unauthorised practice of law in the United States. ${ }^{67}$ Although it has been criticised "as formalistic or unworkable", the distinction between clerical work of typing of legal documents, and preparation of legal documents, is the traditional benchmark for ascertaining whether a non-attorney is engaged in unauthorised practice of law (Lanctot 2002). ${ }^{68}$ Therefore by extrapolation, Reynoso decision could arguably be said to support a limited or restrictive, or clerical use of legal software by non-lawyers.

However, the problem with such narrow legal construction of the non-lawyer use of legal software as espoused in Reynoso, is that legal software are intelligent agents configured to perform complex tasks, ${ }^{69}$ and they would invariably lose their

\footnotetext{
62 Ibid., at $1117-1126$.

63 Ibid., at 1126.

64 Ibid., at 1125 .

65 Ibid., at 1125-1126.

${ }^{66}$ Clerical work is generally perceived as limited to typing of information provided by the consumer without alteration, advice, or proffering of any opinion on the information. For discussion, see Lanctot (2002), supra, note 2, at 833-836.

${ }^{67}$ Ohio State Bar Association v. Newburn, supra, note 3, at 97. The Ohio Supreme Court noted that the practice of law embraced the preparation of legal document. Ibid.

68 Lanctot (2002), supra, note 2, at 834.

69 Susskind (2000), supra note 14 , at $162-176$.
} 
commercial shines and technical appeals if their uses were restricted and subjected to heavy judicial scrutiny and narrow operational confines of clerical chores. Thus, a restricted clerical use of legal software by non-lawyers as implicitly espoused in Reynoso would be no more as commercially useful and attractive as a DVD recorder that could not be used for fear it would infringe copyright. However, the analogy of legal software and a DVD recorder is inherently limited, because whilst the user of a DVD recorder could easily buy a license or a legal right to relevant copyright works, a non-attorney desirous of using legal software beyond its clerical remit, would have to first enroll at a law school and qualify as an attorney.

However, it would be interesting to know how the Court of Appeals in Reynoso would have ruled if the use of the bankruptcy preparation software had not been coupled with outrageous claims of legal expertise and fraudulent misrepresentations by the appellants. In all probability, the Court could still have found the appellants liable for unauthorised practice of law anyway, since, according to the Court's findings, the legal software had suo motu prepared the bankruptcy petition by soliciting information from Reynoso. This task, according to the Court, transcended mere clerical chores and amounted to the provision of legal advice. ${ }^{70}$

The court's narrow views on the acceptable use of legal software by nonlawyers, thus inevitably raises a pertinent question: how do you configure legal software to perform mere clerical, nonlawyer chores? Without doubt this should be possible for programmers. The major downside however is that an enforced restricted design and use of legal software would be commercially useless and unattractive. Moreover, tailoring the design of legal software to avoid the charges of unauthorised practice of law by nonlawyers could potentially stifle the development of legal information science, which is of immense benefits to the legal profession and the judiciary. This dilemma resonates well with other technologies with dual-use potentials, such as copying technologies that facilitate copyright infringements. The best strategy might be a balanced oversight that allows for unfettered development of legal software, while monitoring unscrupulous non-lawyer uses.

A fortiori, it could be logically deduced from the foregoing analyses that a restrictive or clerical non-lawyer use of bankruptcy legal software, or any legal software for that matter, sans legal advice, would not impinge on the unauthorised practice of law legislations in the United States. However, any outright ban on the use of legal software by non-lawyers as such, could most certainly violate the provisions of anti-trust law, the constitutional commerce clause doctrine, the First Amendment right to free speech, and the right to pro se legal representation as guaranteed by the Constitution of United States (Rhode 1981). ${ }^{71}$ These arguments are further explored in the following paragraphs.

\footnotetext{
$\overline{70}$ In re: Jayson Reynoso, supra, note 21 at 1125

71 For discussion, see Rhode (1981).
} 
4.1 Outright ban on non-lawyer use of legal software by States' legislations could likely impinge on federal antitrust laws

The Sherman Antitrust $\mathrm{Act}^{72}$ generally prohibits persons from making any contract or engaging in any combination or conspiracy in restraint of trade or commerce, or monopolising trade among States. ${ }^{73}$ However, States are generally immune from the provisions of the Sherman Act, through the judicially created state action exemption doctrine (Trujillo 2006), as espoused by the US Supreme Court in the 1943 case of Parker v. Brown. ${ }^{74}$

The policy underlying the state action exemption doctrine is the preservation of the principles of federalism that would allow states to pass legislations, which albeit with anticompetitive bent, are designed to protect the welfare of their respective citizens. ${ }^{75}$ However, the state action exemption doctrine is not entirely unqualified, and a brief review of the facts of Parker $v$. Brown is germane in order to fully grasp the significance of the doctrine for the analysis of the possible antitrust barrier to a general ban on the non-lawyer use of legal software.

In Parker, the California legislature approved a marketing programme for agricultural commodities pursuant to the California Agricultural Prorate Act, which generally restricted the way that raisins producers could market their crops. ${ }^{76}$ Specifically, the legislation placed a restriction on competition among raisins growers, and controlled the prices at which raisins were sold to packers who processed and sold the raisins on intestate markets. ${ }^{77}$ The main objectives of the Act were to conserve California's agricultural wealth and prevent economic waste in the marketing of agricultural crops. ${ }^{78}$ The appellee, who was a producer and raisins packer, challenged the legislation on grounds that it impinged on the antitrust provisions of the Sherman Act. ${ }^{79}$

The US Supreme Court rejected the argument that the California legislation contravened antitrust provisions of the Sherman Act, on grounds inter alia that the anti-trust law applied only to persons and corporations, and not to States who, under the Federal system, retained their legislative sovereignty, “... save only as Congress may constitutionally subtract from their authority..." 80

However, states' legislative sovereignty as espoused in Parker, was no carte blanche for states to trammel the provisions of antitrust laws, as no state could exempt anyone or corporation from, or authorise them to violate the provisions of the Sherman Act. ${ }^{81}$ In this regards, the Parker Court did note that there was no

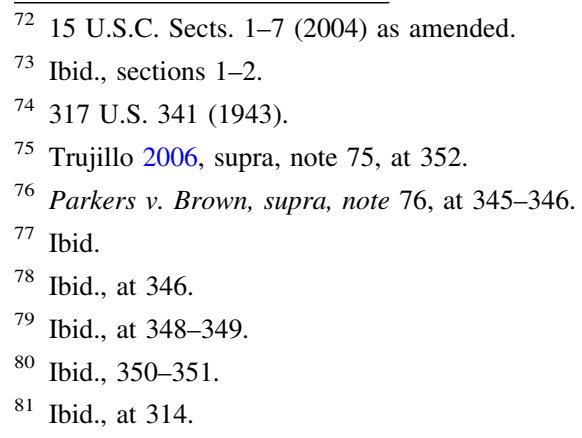


evidence that the state of California or its municipality authorised any private persons or businesses to restrain trade or competition in interstate raisins markets. ${ }^{82}$ Rather the Parker Court observed that:

[i]t is the state, acting through the Commission, which adopts the program and which endorses it with penal sanctions, in the execution of a governmental policy... The state itself exercises its legislative authority in making the regulation and in prescribing the conditions of its application. ${ }^{83}$

A fortiori, a state could still be liable for anti-trust violations if there was evidence that any of the provisions of a state's laws authorised private persons or corporations to enforce the laws or restrain interstate trade or competition. This is exemplified by California Retail Liquor Association v. Midcal Aluminum, ${ }^{84}$ where the US Supreme Court held that a California wine pricing statute violated the Sherman Act, because the price setting and enforcement were to be established by private parties rather than the state of California. ${ }^{85}$ The Supreme Court in Midcal also noted that the arrangement was such that there was no sufficient "active supervision by the state of California". 86 The Court further observed that for a state statute to be exempted from the Sherman Act, it must be "clearly articulated and affirmatively expressed as state policy," while the policy must be "actively supervised by the state itself." 87

By extrapolation, and in the context of the Reynoso decision, unauthorised practice of law legislations are without doubt, clearly articulated policies purposefully designed by states authorities to protect citizens from unqualified attorneys. $^{88}$ The policies could also be said to be actively supervised by states usually through 'Unauthorised Practice of Law Committees', established pursuant to states' laws and acting under the auspices of states' Supreme Courts (Vida 20002001). However, in the context of anti-trust regulation, this would not per se, automatically preclude judicial oversight, especially by federal courts, of the provisions of a state's unauthorised practice of law statute. This proposition is exemplified by Surety Title Insurance Agency v. Virginia State Bar, ${ }^{89}$ where certain provisions of the then state of Virginia's unauthorised practice of law legislation were held violative of antitrust provisions of the Sherman Act. ${ }^{90}$

The plaintiff in Surety Title Insurance Agency had proposed to use lay employees instead of attorneys to prepare the deeds relating to its insurance transactions due to

\footnotetext{
82 Ibid., 351-352.

83 Ibid., at 352 .

84445 U.S. 97 (1980).

85 Ibid., at 103 .

86 Ibid.

87 Ibid., at 150 .

88 Fischer (2000-2001), supra, note 3, at 138-139; Ohio State Bar Association v. Newburn, supra, note 2, at 97 .

89431 F. Supp. 298 (E.D. Va. 1977), vacated and remanded, 571 F.2d 205 (4th Cir.), cert. denied, 436 U.S. 941 (1978) (Hereinafter referred to as Surety Title Insurance Agency).

90 Ibid.
} 
the difficulty it faced in recruiting willing attorneys to do the job. However, the advisory opinions of the Virginia Bar's Unauthorised Practice Committee characterised the plaintiff's proposal as tantamount to unauthorised practice of law, and threatened disciplinary actions against the plaintiff. The plaintiff challenged the Virginia Bar's stance on its recruitment policy as a restraint on trade and a contravention of the antitrust provisions of the Federal Sherman Act. ${ }^{91}$

In reply, the Virginia Bar contended that its unauthorised practice procedures were protected from anti-trust legal challenge by the state action exemption from Federal antitrust laws as espoused by the U.S. Supreme Court in Parker v. Brown. ${ }^{92}$ In other words, that its laws forbidding the hiring of lay employees in the practice of law were exempted from the Sherman Act and not open to a legal challenge. The District Court rejected Virginia Bar's defence on grounds inter alia that the process of its advisory opinion barring plaintiff from using lay employees, was not sufficiently related to legitimate state interest as to outweigh its anti-competitive consequences under the Sherman Act. ${ }^{93}$

Arguably, a state's legitimate interest would be one over which the state could properly assert its legislative sovereignty as espoused by the Supreme Court in Parker v. Brown. ${ }^{94}$ Thus, by extrapolation, any provision in a state's unauthorised practice of law legislation that outrightly ${ }^{95}$ prohibits non-lawyer general use of legal software would have to be sufficiently related to the state's legitimate interests or be a proper subject over which the state could exercise its legislative sovereignty, in order to pass the antitrust muster. However, I would argue that any general ban on the use of legal software by non-lawyers (other than as circumscribed or qualified in Reynoso ${ }^{96}$ ) would most certainly fail the state antitrust exemption tests as espoused in Parker, California Retail Liquor Association, and Surety Title Insurance Agency cases. This is because a general ban on non-lawyer use of legal software would arguably be too overreaching as to derogate from states' legitimate interest and legislative sovereignty over the practice of law in their respective jurisdictions. ${ }^{97}$

This proposition is arguably further validated by the U.S. Supreme Court decision in Goldfarb v. Virginia State Bar, ${ }^{98}$ where the Court held inter alia that the Virginia State Bar statute, requiring County Bar minimum fees, was engaging in

\footnotetext{
91 Ibid.

92 Supra, note 76, at 341-368.

93 Surety Title Insurance Agency v. Virginia State Bar, supra, note 92 at 308.

94 Supra, note 76, at 341; Elizabeth Trujillo, supra, note 75, at 352.
}

95 The emphasis is mine and intended to make a distinction between a restrictive use of legal software as demonstrated by Reynoso and a total non-conditional prohibition of the use of legal software by nonlawyers.

96 In re: Jayson Reynoso, supra, note 21, at 1117.

97 In the United States, all States regulate the practice of law via States unauthorised practice of law legislations and committees that operate under the auspices of States' Supreme Courts. In the State of Ohio for example, Sect. 2(B)(1)(g), Article IV, Ohio Constitution, confers on the Supreme Court of Ohio, original jurisdiction over the "[a]dmission to the practice of law, the discipline of persons so admitted, and all other matters relating to the practice of law." See Ohio State Bar Association v. Newburn, supra, note 2, at 97. For discussion, see Marie A. Vida, supra, note 91, 231 at 235.

98421 U.S. 773, (1975). 
private conduct that was not necessarily immune from antitrust liability. ${ }^{99}$ Significantly, the Court in Goldfarb noted that “...the fact that the Bar is a state agency for some limited purposes does not create an antitrust shield that allows it to foster anti-competitive practices for the benefits of its members." ${ }^{100}$ Viewed from this perspective, any States' regulation on unauthorised practice of law, prohibiting non-lawyers from using legal software or expert systems (other than as circumscribed in Reynoso) could impinge on the provisions of the Sherman Act, and could well be challenged by the aggrieved party for violating same.

\subsection{General ban on non-lawyer use of legal software could run afoul} of the constitutional commerce clause doctrine

A related obstacle to the states' unauthorised practice of law legislations outrightly prohibiting non-lawyers from using legal software or expert systems in law, is the Constitutional Commerce Clause provisions of article 1, Sect. 8, Clause 3 of the United States Constitution, which empowers Congress to regulate commerce and trade nationally and internationally. ${ }^{101}$ In Healy $v$. The Beer Institute, the US Supreme Court held that "This affirmative grant of authority to Congress also encompasses an implicit or 'dormant' limitation on the authority of the states to enact legislation affecting interstate commerce." 102 The Supreme Court had earlier expressed similar views in its decision in Parker v. Brown, ${ }^{103}$ when it noted that:

The governments of the states are sovereign within their territory save only as they are subject to the prohibitions of the Constitution or as their action in some measure conflicts with powers delegated to the National Government, or with Congressional legislation enacted in the exercise of those powers... ${ }^{104}$

Thus, the supremacy of federal laws over states laws is integral to the smooth workings of the US federalism, and the Commerce Clause is the basis for decades' worth of jurisprudence that prohibits states from regulating in ways that could hamper interstate commerce (Oriola 2005), ${ }^{105}$ even in the absence of Congressional action. ${ }^{106}$ The principle has been applied in various commercial settings by the US Supreme Court with varied outcomes (occasioned largely by the peculiar facts of each case) that either prohibited the State legislation in question as unconstitutional, or that absolved it of any contravention of the Commerce Clause. ${ }^{107}$ For example in Parker v. Brown, ${ }^{108}$ the Court held that the California Agricultural Prorate Act,

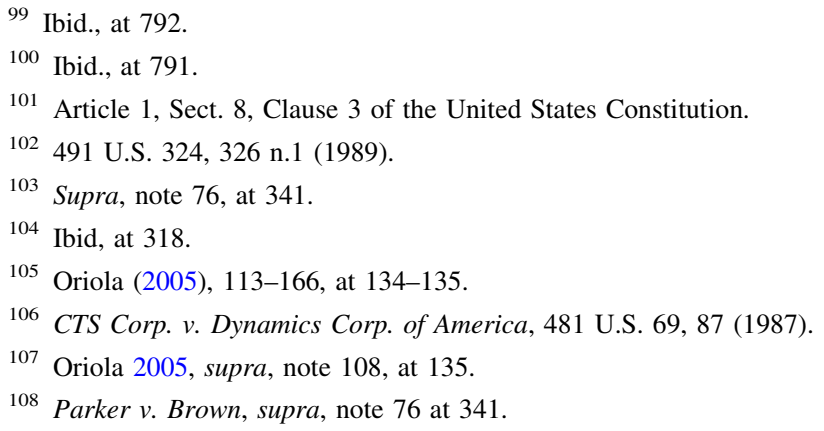


which controlled the sale and purchase of raisins, prior to processing and packing for interstate sale and shipment, did not place undue burden on interstate commerce, and consequently did not contravene the Commerce Clause. ${ }^{109}$ The Parker Court also noted that: "...the grant of power to Congress by the Commerce Clause did not wholly withdraw from the states the authority to regulate the commerce with respect to matters of local concern, on which Congress has not spoken." 110

Therefore, the Commerce Clause could theoretically be invoked by any aggrieved party, against a state law prohibiting non-lawyers from using legal software or expert systems in law, if it could be proven that the said statute interfered with interstate commerce or trade in, or sales of legal software, or that it had encroached on the power of any of the sister states to legislate on the general or commercial use of legal software by non-lawyers. ${ }^{111}$ It is sacrosanct that legal software or expert systems in law is subject of commerce or property rights and therefore trade-able. Moreover, as noted above, legal software or expert systems in law configured for legal services delivery is inherently proprietary and could be subject of intellectual property rights over which the Federal government through Congress has exclusive legislative power (Adelman 1998). ${ }^{112}$ A fortiori, the Constitutional Commerce Clause is a potential obstacle to a state's unauthorised practice of law statute, which outrightly prohibits the general use of legal software by non-lawyers. Such a statute would be vulnerable to a legal challenge premised on grounds that it could undermine Congressional legislations regulating property rights in legal software, or disrupt interstate commerce or trade in legal software.

\subsection{Pro se legal representation and legal software or expert systems in law}

Yet another potential obstacle to a state's unauthorised practice of law legislation that outrightly prohibits the use of legal software by non-lawyers is the citizens' constitutional rights to pro se legal representation. The right was re-affirmed by the US Supreme Court in Anthony Faretta v. California, where the Court held that criminal defendants had a constitutional right to refuse counsel and represent themselves in courts. ${ }^{113}$ In fact, most States have constitutional, evidentiary, or procedural rules guaranteeing citizens' right to pro se legal representation in

\footnotetext{
109 Ibid., at 360-367.

110 Ibid., at 360 .

111 For discussion, see generally Oriola 2005, supra, note 108, at 134-140.

112 Software programs are protectable by patents and copyright laws in the United States. See Adelman (1998), at 105 .

113 Faretta v. California, 422 U.S. 806, 807, (1975). Note however the qualification to the Faretta ruling by the U.S. Supreme Court in Godinez v. Moran, 509 U.S. 389 (1993), where the Court held inter alia that the constitutional right to self-representation in courts could be denied in a criminal case, if the accused was perceived as incompetent or unfit to represent themselves. Also the right to Pro se legal representation does not apply to appellate courts. See the Supreme Court decision in Martinez $v$. California Court of Appeals, 528 U.S. 152, (2000).
} 
courts. ${ }^{114}$ The 2002 Federal Bankruptcy Code is a relevant example of a Federal law that allows for pro se legal representation in Bankruptcy cases. ${ }^{115}$ Therefore, nonlawyers could legally use bankruptcy legal software to prepare and file their own bankruptcy petitions. In the same vein, any pro se litigants would be able to legally use any relevant legal software in the prosecution of their civil or criminal cases in courts. Therefore, any unauthorised practice of law statute that generally prohibits non-lawyer uses of legal software could hinder pro se litigants' access to legal software and indirectly impinge on their constitutional right to self legal representation in courts.

\subsection{The constitutionality of prohibiting the programming, manufacturing,} distributing, and selling of legal software by unauthorised practice of law statutes

Another potential obstacle is the constitutionality of prohibiting or restricting the programming or manufacturing, selling or distributing of legal software by nonlawyers, on grounds of possible violations of unauthorised practice of law statutes. As noted earlier, the Court of Appeals in Reynoso held inter alia that the legal software in question qualified as a bankruptcy petition preparer, ${ }^{116}$ because it supplied legal citations and automatically determined where non-lawyers users should place relevant information. ${ }^{117}$ This is due to the fact that by its very nature, legal software is programmed to process the facts fed into it, and produce appropriate legal instruments and instructions on how to use it, thus accomplishing everything that a lawyer would typically do. ${ }^{118}$ It is thus arguable that legal software, being intelligent systems, is ipso facto an embodied legal advice or a device that could suo motu proffer legal advice.

The pertinent question therefore is whether non-lawyers who programme, manufacture, design, distribute, or sell legal software could be said to be engaging in unauthorised practice of law? In other words, would they be deemed to be making, selling, or distributing legal advice? The answer would, to a large extent, depend on the nature of the legal software and the tasks it was programmed to accomplish. If for example, the legal software was programmed to prepare bankruptcy petitions, pleadings, or wills, or any activities which courts are inclined to regard as lawyers' prerogative, ${ }^{119}$ then non-lawyer programmers who make,

\footnotetext{
114 See for example Article 1, Sect. 10 of the Constitution of the State of Alabama 1901, (as amended) which provides: "That no person shall be barred from prosecuting or defending before any tribunal in this state by himself or counsel, any civil cause to which he is a party."

115 Bankruptcy Code (2002) as amended, supra, note 55.

116 In re: Jayson Reynoso, supra, note 21, at 1123.

117 Ibid., at 1125 .

118 For discussion see, Vincenti 1988, at 205.

119 Due to the fact that wills do create legal rights upon which courts may be called upon to interpret, and that wills making require a certain degree of confidentiality which legal attorneys are obliged to provide, courts often regard wills making as the exclusive preserve of lawyers. For discussion, see Palmer $v$. Unauthorized Practice Committee of the State of Texas, 438 S.W.2d 374 (Tex. Civ. App. 1969), at 377.
} 
distribute or sell the software could be liable for selling or giving of legal advice and vulnerable to unauthorised practice of law charges.

While the Reynoso court refrained from pronouncing on this issue, such a conclusion could be reasonably inferred from the decision. This is especially so because, a la Reynoso, ${ }^{120}$ giving of legal advice is the boundary beyond which nonlawyers handling legal software or legal expert systems in law must not venture. Therefore if the Reynoso software was tantamount to legal advice or the giving of legal advice as the court of Appeals ruled, ${ }^{121}$ then by extrapolation, whoever makes, sells, or distribute legal software could potentially be liable for unauthorised practice of law.

This hypothesis is clearly supported by the decision of the United States District Court of the Northern District of Texas in Unauthorized Practice of Law Committee v. Parsons Technology, Inc. ${ }^{122}$ Parsons Technology Inc., were the manufacturer of a will-creating software program known as "Quicken Family Lawyer" (QFL) version 8.0, which was updated in 1999. QFL software offered over one hundred legal forms bundled with instructions on how to complete them. ${ }^{123}$ The Texas Unauthorized Practice of Law Committee filed a lawsuit challenging the sale of QFL as a contravention of the then Sect. 81.101 of Texas' Unauthorized Practice of Law Statute, which provided as follows:

(a) In this chapter the "practice of law" means the preparation of a pleading or other document incident to an action or special proceeding or the management of the action or proceeding on behalf of a client before a judge in court as well as a service rendered out of court, including the giving of advice or the rendering of any service requiring the use of legal skill or knowledge, such as preparing a will, contract, or other instrument, the legal effect of which under the facts and conclusions involved must be carefully determined.

(b) The definition in this section is not exclusive and does not deprive the judicial branch of the power and authority under both this chapter and the adjudicated cases to determine whether other services and acts not enumerated may constitute the practice of law. ${ }^{124}$

The District Court ruled in favour of Texas Unauthorised Practice of Law Committee, by permanently injuncting Parsons Technology Inc from selling and distributing QFL software, on grounds that their actions amounted to unauthorised practice of law. ${ }^{125}$ Parsons Technology Inc appealed the injunction, and while the appeal was pending, Texas legislature amended Sect. 81.101(a) of the Unauthorised Practice of Law statute to exclude inter alia, the design, creation, publication, distribution, display, or sale of computer software provided the products conspicuously state that they were not a substitute for legal advice. The full terms of the amendment is best captured in the words of the statute which provides thus:

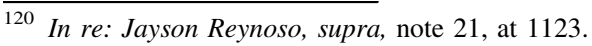

121 Ibid, at 1125.

122 Unauthorized Practice of Law Committee v. Parsons Technology, Inc 1999 WL 47235.

${ }^{123}$ Ibid.

124 Tex. Govt. Code Ann. Section 81.101 (West 1998) (amended in 1999).

125 Supra, note 125.
} 
In this chapter, the "practice of law" does not include the design, creation, publication, distribution, display, or sale by means of an internet web site, of written materials, books, forms, computer software, or similar products if the products clearly and conspicuously state that the products are not a substitute for the advice of legal attorney... ${ }^{126}$

Thus, the amendment effectively reversed the District Court's injunction, and the Court of Appeals had little choice but to subsequently vacate the injunction against Parsons Technology Inc. ${ }^{127}$ It is instructive to note that Texas is the only one out of fifty other states that makes conditional exception for designing or making of legal computer software in its unauthorised practice of law legislation. Thus in other states, the design, creation, publication, or distribution of legal computer software could still be held violative of their unauthorised practice of legislations. This divergent approaches further underscores the imperatives of a uniform and coherent definitional constructs of unauthorised practice of law across the United States.

Thus if other states fail to emulate the amendment to Texas' unauthorised practice of law statute, their laws could be vulnerable to the First Amendment free speech challenge, if confronted with facts similar to Parsons Technology Inc case. Without doubt, legal software or expert systems in law is a critical tool for communicating legal information, and any attempt to suppress its design, manufacture, distribution, or sale, could potentially impinge on the First Amendment right to free speech, ${ }^{128}$ which according to Gerald Treece, “...absolutely stands for the free flow of information" (Treece 1999). ${ }^{129}$

An analogous but apt example was the 1967 case of New York County Lawyers Association v. Dacey, where the New York Court of Appeals held inter alia that the state's attempt to prohibit the sale of a popular probate book written by Norman Dacey, (a non-attorney with 35 years experience in estate management) and entitled "How to Avoid Probate", contravened the First Amendment right to freedom of expression. ${ }^{130}$ The Court had noted that while lawyers were uncomfortable that the book had encroached on their rights, it was no justification for banning the book. ${ }^{131}$ In the Court's words:

It is a prized American privilege to speak one's mind, although not always with perfect good taste, on all public institutions... Free and open discussion or even controversy could lead to reforms, if needed, or improvement where desirable. Books purporting to give advice on the law and books critical of law

\footnotetext{
126 Tex. Govt. Code Ann. Section 81.101 (Supp. 2000).

127 Unauthorized Practice of Law Committee v. Parsons Technology Inc., 179 F.3d 956 (5th Cir. 1999).

128 The First Amendment to the United States Constitution provides that: "Congress shall make no law respecting an establishment of religion, or prohibiting the free exercise thereof; or abridging the freedom of speech, or of the press; or the right of the people peaceably to assemble, and to petition the Government for a redress of grievances." For discussion, see Fischer (2000-2001), supra, note 3, at 136-137.

129 Treece (1999), 971, at 972.

130283 N.Y.S. 2d 984, 996 (N.Y. App. Div. 1967), revised on the dissenting opinion, 234 in N.E. 2 d 459 (N.Y. 1967).

131 Ibid., at 1000-01.
} 
and legal institutions have been and doubtless will continue to be published. Legal forms are available for purchase at many legal stationery stores. Unless we are to extend a rule of suppression beyond the obscene, the libelous, utterances of or tending to incitement, and matters simply characterized, there is no warrant for the action here taken. ${ }^{132}$

Significantly, the Court went ahead to qualify Dacey's free speech right to publish his book, by subordinating it to societal overall interests. In the Court's words: "if the exercise of Dacey's right to freedom of speech by this publication violates reasonable standards erected for the protection of society, or of important interests of society, his right could be subordinated for the common good and the protection of the whole." ${ }^{133}$ However, this qualification is not without precedent for there are no absolute civil rights as such. For example a person's freedom of movement could be legally constrained by a lawful imprisonment meted out for a crime committed against the State.

Moreover, and significantly, the First Amendment not only protects free speech, but also guarantees access to it, and legal advice, whether embodied in software or a book is inherently informational, and access to it would be guaranteed by the First Amendment. This proposition is supported by the US Supreme Court in Board of Trustees State University of New York v. Fox. ${ }^{134}$ The university had banned certain persons who were engaged in for-profit activities from university dormitories. ${ }^{135}$ The ban was challenged by the Respondents, and the Supreme Court set it aside on grounds inter alia that the ban would prevent students from receiving legal advice in their rooms, and that legal advice was a constitutionally protected speech. ${ }^{136}$ Viewed from the foregoing analyses, the First Amendment is a potential obstacle to any unauthorised practice of law legislation that bans non-lawyers from making, designing, distributing, and selling legal software.

\section{Statutory and judicial constructs of unauthorised practice of law legislations: a conundrum}

If anything, the Parsons Technology case demonstrates the inherent ambiguity in the statutory conception and judicial constructs of the meaning of 'unauthorised practice of law' in the United States. This ambiguity makes it all the more difficult for coherent judicial analyses of when the use of legal software by non-lawyers would infringe unauthorised practice of law legislations. Although the Texas legislative amendment infused the debate with relative certainty, and brought immediate closure to the Parsons Technology case, non-lawyers making, selling, distributing, or using legal software are arguably vulnerable to unauthorised practice

\footnotetext{
132 Ibid.

133 Ibid., at 1000 .

134492 U.S. 469 (1989).

135 Ibid., 471-472.

136 Ibid., at 482.
} 
of law charges in other states without the Texas-type conditional statutory exemption.

Without doubt, the definition of what constitutes the practice of law in the United States has almost always exuded legal and political connotations (Rose 2002), ${ }^{137}$ while its juridical and statutory constructs often vary from jurisdiction to jurisdiction (Lanctot 2002). ${ }^{138}$ For example, earlier attempts by the American Bar Association at regulating unauthorised legal practice via a regime of "Statement of Principles" were stiffly resisted (Denckla 1999, note 19), and held violative of antitrust regulations by the US Supreme Court (Podgers 1980). ${ }^{139}$

The main bane of regulating unauthorised practice of law activities lays in the difficulty of conceptualising the exact parameters of what constitute the practice of law. ${ }^{140}$ Due to inherent statutory ambiguity, Judges in the United States have been equally flummoxed and unable to nail down the exact meaning of what the practice of law is, and have tended to take "an ad hoc approach" to deconstructing the term. ${ }^{141}$ For example, in the Reynoso case ${ }^{142}$ the United States Court of Appeals for the Ninth Circuit acknowledged the intractability of the term, which California courts have accepted as including “...legal advice and counsel and the preparation of legal instruments and contracts." 143 The Court of Appeals then drew on the earlier California case of Baron v. Los Angeles, ${ }^{144}$ where the court opined that "ascertaining whether a particular activity falls within this general definition may be a formidable endeavor." 145

However, the proliferation of online non-lawyer legal documents providers as typified by Reynoso makes a clearer and definitive conception of the practice of law imperative and urgent. Computerised web-based legal programs offering legal services are a putative force, with relatively greater capabilities to encroach on the turfs of authorised legal practitioners, than previously possible via books, ${ }^{146}$ due to internet ubiquity and the relative ease of content dissemination and access. For instance, a definitive statutory conception of the practice of law, in the context of the sale and distribution of legal software by non-lawyers, as exemplified by Texas legislative amendment, is imperative for clearer judicial interpretation.

The ABA's Centre for Professional Responsibility, through its Task Force, proposed a model definition for the practice of law in September 2002. ${ }^{147}$ According to the preliminary draft, the practice of law is defined as "...the

\footnotetext{
137 Rose (2002), at 585.

138 See Lanctot (2002), supra note 2 at 811-812.

139 For discussion, see Podgers 1980.

140 See Lanctot 2002, supra note 2 at 820-821.

141 Ibid., at 812.

142 In re: Jayson Reynoso, supra, note 21, at 1125.

143 Ibid.

144 Supra, note 58, at 353.

145 In re: Jayson Reynoso, supra, note 21, at 1125.

146 See for example, New York County Lawyers' Association. v. Dacey, supra, note 133 at 996.

147 See Centre for Professional Responsibility, ABA, Task Force on the Model Definition of the Practice of Law, at http://www.abanet.org/cpr/model_def_home.html (last accessed on 2 August 2010).
} 
application of legal principles and judgment with regard to the circumstances or objectives of a person that require the knowledge and skill of a person trained in the law." 148 The preliminary definition of the 'Practice of Law' then listed the circumstances under which a person would be presumed to be practising law. ${ }^{149}$ These include giving advice or counsel to persons on their legal rights and responsibilities or to those of others, ${ }^{150}$ selecting, drafting, or completing legal documents or agreements that affect the legal rights of others, ${ }^{151}$ representing a person before an adjudicative body, including but not limited to documents preparation, or filing, or conducting discovery, ${ }^{152}$ or negotiating legal rights or responsibilities on behalf of a person. ${ }^{153}$ Anyone engaging in unauthorised practice of law shall be subject to criminal and civil penalties. ${ }^{154}$ This recommendation was adopted by the American Bar Association on August 11, 2003. ${ }^{155}$ The ABA has recommended that every state and territory adopt a definition of the 'Practice of Law' that reflects the one in the model definition. ${ }^{156}$

However, the ABA model definition did not address the place of legal software as Texas definition did by conditionally exempting the sale or distribution of legal software from the statutory scope of unauthorised practice of law. For sure, legal software will continually evolve and increase in sophistication, and there is little the legal profession could do to stifle its sale and use by non-lawyers. Any attempts at stifling the manufacture and use of legal software could most certainly raise legal roadblocks ranging from antitrust, First Amendment right to free speech, pro se legal representation, to constitutional commerce clause barriers as analysed in this paper.

Significantly, apart from potential legal and constitutional pitfalls, a sustained opposition to the general use of legal software could potentially undermine the advancement of legal information technological tools and information science. In my view, the Texas unauthorised practice of law legislation as amended is a very good model that could obviate potential legal squabbles with regards to the sale or distribution of legal software. Adopting the Texas model by other states would help guide the courts in cases similar to Reynoso, in delineating the parameters within which non-lawyers could use legal software. It is suggested that a uniform statutory definition of the practice of law akin to that of Texas be adopted by states across the United States. Significantly, non-lawyers using legal software other than pro se

\footnotetext{
148 Ibid.

149 Ibid.

150 Ibid.

151 Ibid.

152 Ibid.

153 Ibid.

154 Ibid.

155 See American Bar Association, Task Force on the Model Definition of the Practice of Law, Standing Committee On Client Protection, Washington State Bar Association, Report To The House Of Delegates, Recommendation, at http://www.abanet.org/cpr/model-def/recomm.pdf (last accessed on 2 August 2010). 156 Ibid.
} 
litigants should refrain from representing themselves as legal experts or proffer legal advice as exemplified by Reynoso case.

\section{Conclusion}

This paper critically analyses the judgment of the United States Court of Appeals for the Ninth Circuit in Reynoso case. The appellants, who were non-lawyers, were indicted with unauthorised practice of law for offering bankruptcy petition services via expert systems in law configured for filing bankruptcy petition forms. The Court of Appeals found inter alia that appellants were bankruptcy petition preparers, and that they had exceeded their clerical remit by offering legal advice and legal services in contravention of California law regulating legal practice and 11 U.S.C. Sect. 110 of the Bankruptcy Code (2002). While examining the legal ramifications of the use of legal software or expert systems in law by non-lawyers, the paper critically reviews the factual circumstances of Reynoso decision in the context of juridical and statutory constructs of unauthorised practice of law in the United States. The paper posits that the Reynoso decision should be viewed as a one off decision bound by its peculiar facts, and not good law for the broad proposition that non-lawyers cannot use expert systems in law.

The paper however notes the narrow confines set by Reynoso, within which nonlawyers could use legal software. However, while Reynoso provides judicial guidance on how non-lawyers could use legal software, (with the exception of the state of Texas) there is no nation-wide statutory guidance on whether the sale or distribution of legal software would constitute unauthorised practice of law. The paper also notes that any efforts to undermine the general use of legal software by non-lawyers could raise constitutional and legal obstacles ranging from antitrust provisions of the Sherman Act, the right to pro se legal representation, constitutional commerce clause doctrine, to the First Amendment right to free speech. It is suggested that every state adopts the model definition of the practice of law that is akin to that of the state of Texas, which clearly exempts the sale of legal software from unauthorised practice of law, provided this is coupled with express and conspicuous disclaimer that the software is no substitute for legal advice. This would provide a statutory definitional certainty, in the same way that Reynoso case, to some extent, provides judicial certainty on the scope of non-lawyer use of legal software in the United States.

\section{References}

Adelman M (1998) Cases and materials on patent law. West Group, St. Paul, p 105

Denckla D (1999) Nonlawyers and the unauthorized practice of law: an overview of the legal and ethical parameters. Fordham Law Rev 67:2585

Fischer J (2000-2001) Policing the self-help legal market: consumer protection or protection of legal cartel? Indiana Law Rev 34:121-153 at 138-139 
Gibeaut J (1998) Squeeze play: as accountants edge into the legal market, lawyers may find themselves not only blinded by the assault but also limited by professional rules. ABA J 84:42-47

Glass G, Jackson K (2000-2001) The unauthorized practice of law: the internet, alternative dispute resolution, and multidisciplinary practice. Georgetown J Leg Ethics 14:1195-1210

Justice K (1991) There goes the monopoly: the California proposal to allow non-lawyers to practice law. Vanderbilt Law Rev 44:184-185

Lanctot C (2002) Scriveners in cyberspace: online documents preparation and the unauthorized practice of law. Hofstra Law Rev 30:811-854

Leef G (1997) Lawyer fees too much? The case for repealing unauthorized practice of law statutes. Regul Cato Rev Bus Gov 20(1). Available at http://www.cato.org. Last accessed 2 June, 2010

Messina J (2000) Lawyer + layman: a recipe for disaster! Why the ban on MDP should remain. Univ Pittsbg Law Rev 62:367-372

Morrison R (1989) Market realities of rule-based software for lawyers: where the rubber meets the road. In: Proceedings of the 6th international conference on artificial intelligence and the law. ACM Press, New York, pp 33-36

Oriola T (2005) Regulating unsolicited commercial electronic mails in the United States and the European Union: challenges and prospects. Tulane J Technol Intellect Prop 7:134-135

Oskamp A, Lauritsen M (2002) AI in law practice? So far, not much. Artif Intell Law 10:227-236

Palomar J (1991) The war between attorneys and lay-conveyancers: empirical evidence says cease fire! Conn Law Rev 31:423-530

Podgers J (1980) Statements of principles: are they on the way out? ABA J 66:129

Rentz M (2005) Laying down the law: bringing down the legal cartel in real estate settlement services and beyond. Georgia Law Rev 40:293-333

Rhode D (1981) Policing the professional monopoly: a constitutional and empirical analysis of unauthorized practice prohibitions. Stanford Law Rev 34:1-99

Rose J (2002) Unauthorized practice of law in Arizona: a legal and political problem that won't go away. Ariz State Law J 34:585

Schwab S (2000) Bringing down the bar: accountants challenge meaning of unauthorized practice of law. Cardozo Law Rev 21:1425-1468

Susskind R (1987) Expert systems in law: a jurisprudential inquiry. Oxford University Press, Oxford, p 3

Susskind R (1996) The future of law: facing the challenges of information technology. Oxford University Press, Oxford, pp 86-87

Susskind R (2000) Transforming the law: essays on technology justice and the legal market place. Oxford University Press, Oxford, pp 162-176

Treece T (1999) The law as a foreign language. South Tex Law Rev 40:972

Trujillo E (2006) State action antitrust exemption collides with regulation: rehabilitating the foreseeability doctrine. Fordham J Corp Financ Law 11:349-352

Vida M (2000-2001) Legality of will-creating software: is the sale of computer software to assist in drafting will documents considered the unauthorized practice of law? Santa Clara Law Rev 41:231-235

Vincenti R (1988) Self-help legal software and the unauthorized practice of law. Comput Law J 185:185-205 